\title{
Analysis of Physical and Chemical of Starch Lindur (Bruguiera Gymnorrhiza), Pedada (Sonneratia Casiolaris) and Api-Api (Avicennia Marina)
}

\author{
Melkhianus Hendrik Pentury \\ Health Faculty, Indonesian Christian University In The Moluccas. Jl. Ot Patimaepau, Ambon \\ E-mail: meckypentury@gmail.com
}

Received: Dec. 17, 2016 Accepted: Dec. 22, 2016 Published: December 30, 2016

doi:10.5296/jee.v7i2.10610 URL: http://dx.doi.org/10.5296/jee.v7i2.10610

\begin{abstract}
Mangrove is one of the coastal ecosystem which highly beneficial for human, several type of mangrove that were commonly used as food source for human were Bruguiera gymnorrhiza, Sonneratia casiolaris and Avicennia marina. With high carbohydrate content, these three mangrove has the potential to be processed into starch or flour. Characterization review of physical and chemical traits of starch from Bruguiera gymnorrhiza, Sonneratia casiolaris and Avicennia marina was done in Health Laboratory of Health Agency in Maluku Province and Community Health Study Laboratory in Health Faculty of Universitas Kristen Indonesia Maluku. Physical and chemical analysis done consist of coarse fiber, protein, fat, water content, ash content, sucrose content, white degrees, water absorbance, starch and amylose analysis. Result of this study showed that sucrose content of Bruguiera gymnorrhyza was $19,5 \%$, of Sonneratia casiolaris was $42,1 \%$ and of Avicennia marina was $21,4 \%$. For sucrose content of starch were $10,85 \%, 15,25 \%$ and $11,15 \%$. White degree of flour were $39,45 \%$, $45,17 \%$ and $40,45 \%$ respectively. White degree for starch were $57,72 \%, 66,39 \%$ and $60,8 \%$. Coarse fiber content for flour of Bruguiera gymnorrhiza was 1,24 ml/gr, of Sonneratia casiolaris $0,97 \mathrm{ml} / \mathrm{gr}$, and of Avicennia marina $1,05 \mathrm{ml} / \mathrm{gr}$. Water absorbance for starch of Bruguiera gymnorrhize was the highest with $3,57 \mathrm{ml} / \mathrm{gr}$, followed by Sonneratia casiolaris with $1,46 \mathrm{ml} / \mathrm{gr}$ and Avicennia marina with 2,33 ml/gr. Water content of Bruguiera gymnorrhiza starch was between $9,02 \%-10,77 \%$. Water content of Sonneratia casiolaris starch was between 10,72\%-11,90\%. Water content of Avicennia marina starch was between 7,69\%-9,61\%. Ash content of Bruguiera gymnorrhiza starch was about 4,65\%-5,65\%. Ash content of Sonneratia casiolaris starch was about 4,10\%-4,17\% and ash content of Avicennia marina starch was about $3,87 \%-4,16 \%$. Highest protein content for each type was Bruguiera
\end{abstract}




\section{Macrothink}

Journal of Environment and Ecology ISSN 2157-6092 2016, Vol. 7, No. 2

gymnorrhiza with $3,31 \%$, Sonneratia casiolaris with $1,69 \%$ and Avicennia marina with 2,20\%. Fat content for each type was $0,89 \%, 0,58 \%$ and $0,94 \%$ respectively. Coarse fiber content for each type was $1,40 \%, 0,51 \%$ and $0,99 \%$. Starch of Bruguiera gymnorrhiza was 73,19\%, of Sonneratia casiolaris was $61,95 \%$ and of Avicennia marina was 70,71\%. Amylose content for those three were $31,45 \%, 20,28 \%$ and $27,69 \%$. This study contribution was to obtain starch sources as food material.

Keywords: Bruguiera gymnorrhiza, Sonneratia casiolaris, Avicennia marina, Characterization, Starch 


\section{Introduction}

Mangrove ecosystem is the unity between mangrove vegetation community which associated with fauna and microorganism thus it could grow and developed along coastal area particularly in tidal areas, lagoons, and protected estuaries with muddy substrate or sandy mud to create a balance and sustainable natural environment. Mangrove that commonly used as food sources were Bruguiera gymnorrhiza, Sonneratia casiolaris and Avicennia marina which were known as lindur fruit, pedada fruit and api-api. These three type of mangroves were commonly seen in most areas in Indonesia, with its high nutrition content has become its own appeal for its management for people's interest.

Food source availability in mangrove ecosystem, until now was not yet sufficiently developed, and its management was still limited only in local scale. This was due to mangrove ecosystem utilization was more directed to its ecological benefit, also its palatability value of its products was still very low due to very limited processing system. Therefore, food processing model should be developed for carbohydrate sources in this type of ecosystem.

Food is something vital for human life, since without food, it was impossible to survive. Regarding strategic role of food, related with human resource's quality development, economic security and national security, its availability should be in sufficient amount, nutritious, balance, evenly spread, and economical or within people's buying capacity (Ardiansyah, 2005).

Providing food for the people in large amount every day has obliged all components of society to bring their best effort to it, including in looking for new food sources that could be managed to help local food source in meet the demands of food that largely come from rice and flour.

Based on the latest Susenas data, amount of people in Indonesia has reached 254,9 millions people, which increase from 2014 with 252 million people (BPS, 2015). Growth rate in Indonesia currently about 1,49 percent, with this rate every year the amount of people in Indonesia would increase about 4,5 millions people (BKKBN, 2015). In this condition, demands on food would increase and eventually could create food crisis. Therefore, efforts in trying to meet food demands should be done continuously.

Domestic food issue would be related with rice and flour in which flour was more adaptive than domestic food such as gaplek, maize rice, sagu or sweet potatoes although in several areas some people still consumed those traditional foods (Widowati, 2003). Potential in regional resources and natural resources in Indonesia has create various food sources, either carbohydrate, protein or fat food sources thus food development strategy should be directed toward potential in regional resources and specific food sources.

Building food security is the responsibility of all elements, either the government or the people that could initiated from household level, regional level and then national level. To create this food security, one of the effort that could be done was by conducting food diversification to various food consumption, with balance nutrition and safe-to-consumed 
food, also by looking and developing the existed local food sources (Ardiansyah, 2005).

Local food source that has been utilized recently was food sources of mangrove plants such as Bruguiera gymnorrhiza, Sonneratia casiolaris and Avicennia marina which was started to be developed in several areas in Indonesia. Processing phase in this efforts would usually use the flour which traditionally processed by the people, therefore in-depth review should be done toward good processing mechanism, including in starch and flour-making that should be in accordance with standard processing where its yield could be used to meet the demand for the people.

\section{Material and Method}

\subsection{Material}

Starch and flour were obtained from hypocotyl of Bruguiera gymnorrhiza, fruit of Sonneratia casiolaris and fruit of Avicennia marina which gained from Coastal area of Ambon Bay in Maluku Province. Chemical substances used in this study were Natrium metabisulfite $\left(\mathrm{Na}_{2} \mathrm{~S}_{2} \mathrm{O}_{5}\right)(p a)$. Material for amylose content analysis were $\mathrm{NaOH} 1 \mathrm{~N}$, protelium ether solute $\mathrm{H}_{2} \mathrm{SO}_{4}, \mathrm{HCl} 25 \%, \mathrm{H}_{3} \mathrm{BO}_{3}$, phenolphtalein indicator, blue metilen indicator, alcohol $10 \%$, $\mathrm{NaOH} 45 \%$, nelson reagent, arsenomolybdat reagent, sodium tetraborate, formaline $38 \%$, methanol, ethanol $80 \%$, folin reagent, $\mathrm{Na}_{2} \mathrm{CO}_{3}$, lowry reagent and aquades ( $p a$ ).

Tools used to make flour and starch from hypocotyl of Bruiguiera gymnorrhiza, fruit of Sonneratia casiolaris, and fruit of Avicennia marina were sieve 80 mesh and sieve 60 mesh, cabinet dryer, and India flour-making tools, analytical scales, blender, plastic container, pan, gas stove, and spoon. Tools used for analysis consist of kjehdal flask, destilation tools, UV spectrophotometre, and cuvettes, soxhlet tools, HPLC, color reader, analytical scales Ohaus AP-310-O (Switzerland), reverse cooler, magnetic stirrer, Stuart Scientific and stirrer stone, oven type U-40 (Schurzart W-Germany), petridishes, dessicator, glass ware, water bath, centrifuge, weighing bottle, hot plate and $\mathrm{pH}$ meter.

\subsection{Methods}

This study was done in Health Laboratory in Health Agency of Maluku Province and Community Health Study Laboratory in Health Faculty of Universitas Kristen Indonesia Maluku, from March 2016 until August 2016. Method used in this study was experimental method. Complete Random Design (RAL) was used as its study design using two replications. Flour was made using dry processing by peeling and washing the ingredients, cutting it into smaller pieces, drying it and then grind or blending it and eventually sieved using mesh 60 . Flour procedure was given in Figure 1.

For starch, hypocotyl of Bruguiera gymnorrhiza, fruit of Sonneratia casiolaris and fruit of Avicennia marina was peeled and washed then it was cut into small pieces. For hypocotyl of Bruguiera gymnorrhiza, we should eliminate its tannin compound by submerging it in water for 48 hour, water was replaced every 6 hours with ratio 1:2. This treatment was done since Bruguiera gymnorrhiza in pilot experiment is known to contain tannin compound. Afterward, blanching was done for 5 minutes for all three types of mangroves. Starch 
extraction was done by submerging pieces of hypocotyl of Bruguiera gymnorrhiza, fruit of Sonneratia casiolaris and fruit of Avicennia marina in $0 \%, 0,2 \%, 0,3 \%$ natrium metabisulfite solution $\left(\mathrm{Na}_{2} \mathrm{~S}_{2} \mathrm{O}_{5}\right)$ for 0,5 , and 10 minutes using AACC (1983) extraction method with modification that was used by Waliszewski (2003). Subsequently, starch substrate was dried, and sieved using 80 mesh. Starch-making procedure was given in Figure 2.
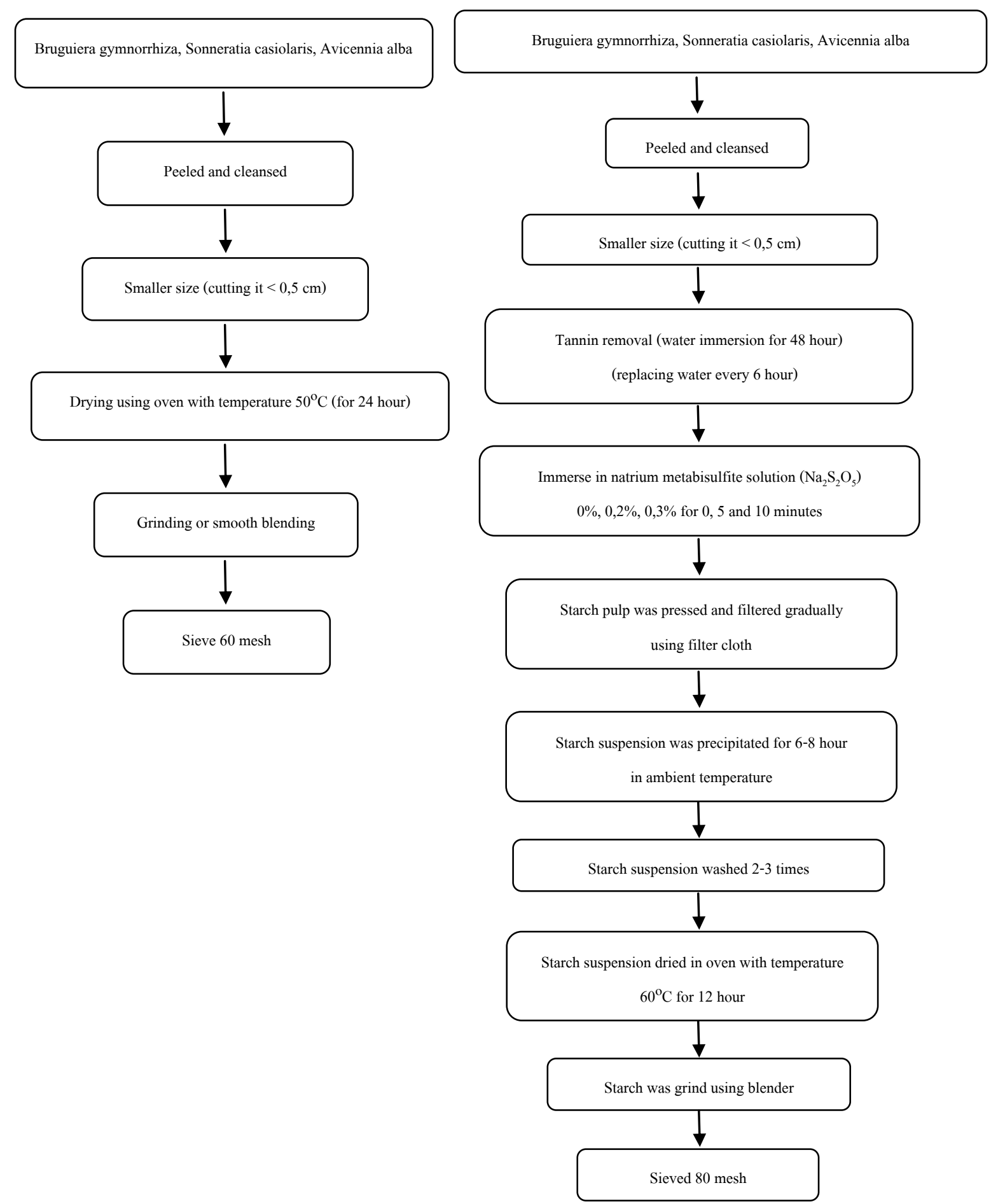

Figure 1. Flour-making Procedures

Figure 2. Starch-making Procedures 


\subsection{Analysis Procedures}

Analysis procedures for characterization in physical and chemical traits consist of amylose analysis using Juliano's (1971) modification method. Water content was analyzed using oven in $105^{\circ} \mathrm{C}$ until it reached constant weight. Ash content was analyzed by ashing it inside Tanur, heating it using temperature $500^{\circ} \mathrm{C}-600^{\circ} \mathrm{C}$ for 6 hours (SNI 01-2891-1992). Determination of fat content was using Soxhlet method with petroleum ether as solute (AOAC, 1984). Protein determination was done using Kjeldhal micro method (AOAC, 1984). To count coarse protein, we used factor 6,25. Fiber content was determined by hydrolizing samples using acid solution, and with dilute alkali solution (SNI 01-2981-1992). Starch analysis was done using Somogy Nelson reagent in Hidayat (1988). Sucrose content analysis was done to found out efficiency in flour and starch utilization of these three mangroves as food products. White degree analysis was done using whiteness measurement or Whiteness meter.

\section{Result and Discussion}

\subsection{Characterization for Physical Traits}

\section{Sucrose content of Flour and Starch}

Physical trait of flour and starch observed in this study were sucrose content and whiteness degree, result showed that sucrose content in flour of Bruguiera gymnorrhiza was 19,5\%, of Sonneratia casiolaris was $42,1 \%$ and of Avicennia marina was $21,4 \%$. This result showed that these three mangroves has quite high sucrose content thus it was highly potential to be made as flour. It was the same with sucrose content in starch of Bruguiera gymnorrhiza was $10,85 \%$, of Sonneratia casiolaris $15,25 \%$ and of Avicennia marina $11,15 \%$, these three has the potential to be made as starch source, however for Bruguiera gymnorrhiza it has the lowest sucrose content either in flour or in starch compared to Sonneratia casiolaris and Avicennia marina. This might be due to peeling process of Bruguiera gymnorrhiza where some of its flesh was peeled away, thus affecting sucrose content in starch of Bruguiera gymnorrhiza. Although it has smallest starch's sucrose content than the other two, but it still large enough as starch content in a material. This result was given in Figure 3.

\section{Whiteness Degree of Flour and Starch}

Bruguiera gymnorrhiza, Sonneratia casiolaris and Avicennia marina were types of mangrove that have less white fruit flesh, except for Sonneratia casiolaris that has whiter fruit flesh thus in flour-making and starch extraction it would highly affecting its color due to oxidation process. Results in flour-making and starch extraction showed different color for flour and starch, a bit brownish for all starch products, while almost brown for all the flours. Results of this study showed that whiteness degree for flour is smaller than whiteness degree for starch, which were Bruguiera gymnorrhiza for flour 39,45\% and for starch 57,72\%, Sonneratia casiolaris for flour 45,17\% and for starch 66,39\% also Avicennia marina for flour 40,45\% and for starch $60,87 \%$. These results were obtained since flour-making process was done without treatment of submerging it in whitening solution, thus the flour product compared to the extraction product was a bit more brownish. While during starch extraction process, submerging was done using natrium metabisulfite that works as browning suppressor since 
browning was due to the work of polyphenol enzymes within starch (Syarief and Irawati, 1988). Natrium metabisulfite also acts as material to maintain color brightness of the product, thus starch's whiteness degress became higher than flour's whiteness degree, these results was given in Figure 4.

\section{Water Absorbance for Flour}

Water absorbance of flour obtained from Bruguiera gymnorrhiza, Sonneratia casiolaris and Avicennia marina were different from one another. Flour from Bruguiera gymnorrhiza has $1,24 \mathrm{ml} / \mathrm{gr}$, Sonneratia casiolaris has $0,97 \mathrm{ml} / \mathrm{gr}$, while Avicennia marina has $1,05 \mathrm{ml} / \mathrm{gr}$. This measurement showed that every 1 gram of flour from Bruguiera gymnorrhiza would be able to absorp 1,24 $\mathrm{ml}$ water. Similar with this, 1 gram flour from Sonneratia casiolaris would be able to absorp 0,97 $\mathrm{ml}$ water. Also, 1 gram flour from Avicennia marina would be able to absorp 1,05 $\mathrm{ml}$ water. Water absorbance ability of these three mangroves were different due to each type has its own hypocotyl and fruit characteristic. Bruguiera gymnorrhiza has propagule or hypocotyl shape, while Sonneratia casiolaris has large fruit just like an apple, and Avicennia marina has small fruit more like grains in its shape.

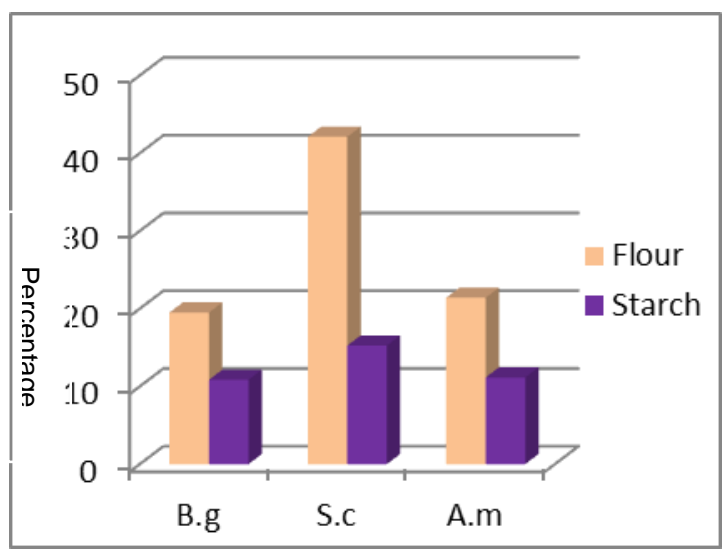

B.g =Bruguiera gymnorrhiza

S.c =Sonneratia casiolaris

A.m =Avicennia marina

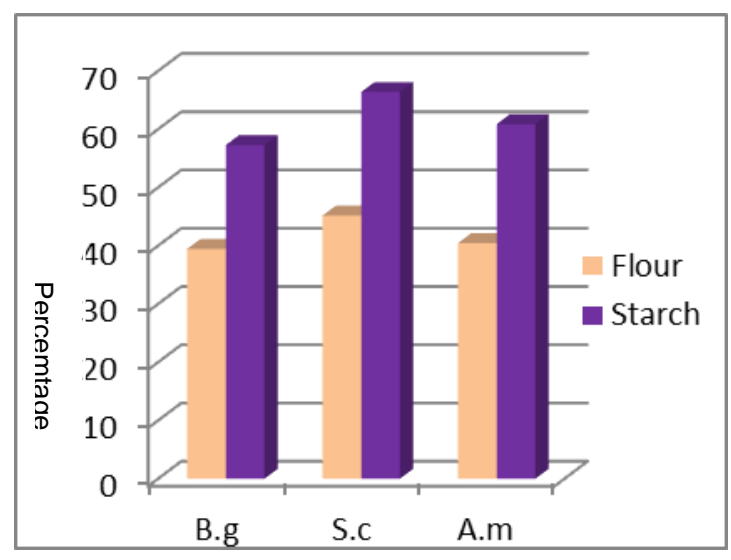

B.g =Bruguiera gymnorrhiza

S.c =Sonneratia casiolaris

A.m=Avicennia marina

Figure 3. Sucrose content of flour and starch

Figure 4. Whiteness degree of flour and starch

Flour granule would able to absorp water in certain amount and make the flour rise, this condition would highly determining dough trait made from this material, thus higher water absorbance would means more elastic dough could be produced (Santoso et al., 2009). Water absorbance analysis results can be seen in Figure 5. 


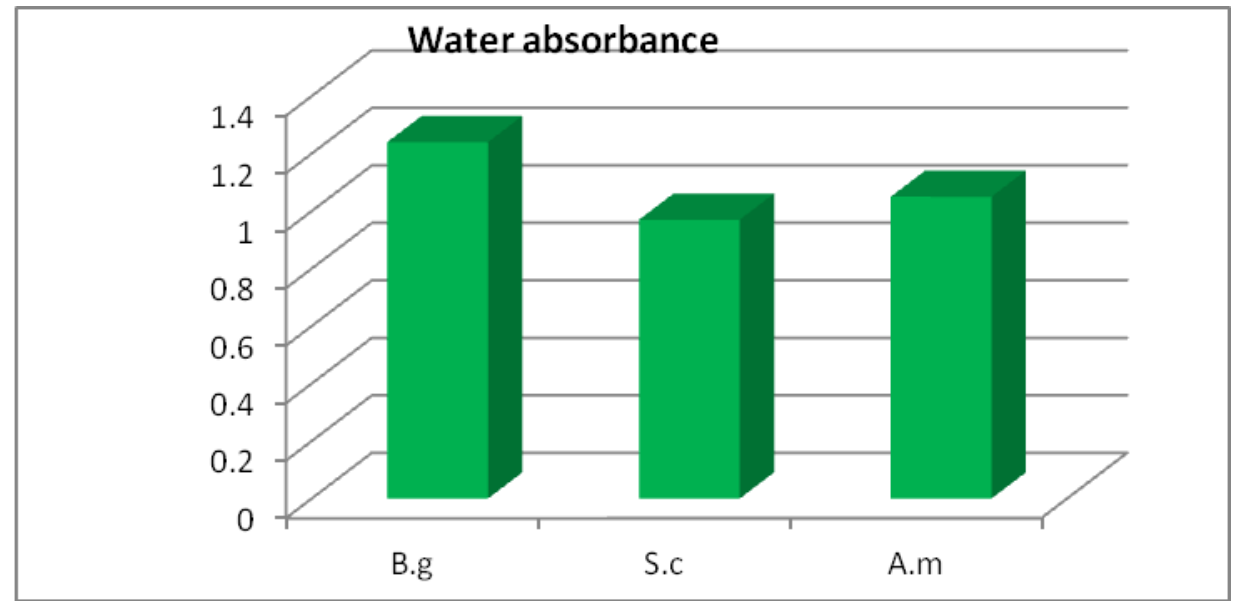

$$
\begin{aligned}
& \text { B.g = Bruguiera gymnorrhiza } \\
& \text { S.c = Sonneratia casiolaris } \\
& \text { A.m = Avicennia marina }
\end{aligned}
$$

Figure 5. Water absorbance for flour

\section{Water Absorbance for Starch}

Starch from Bruguiera gymnorrhiza, Sonneratia casiolaris and Avicennia marina were obtained by immersing it using natrium bisulfite thus each starch would have improved water absorbance capacity along with increasing concentration of natrium metabisulfite being used. Starch obtained from Bruguiera gymnorrhiza, by immersing it using 0,3\% natrium metabisulfite has the highest water absorbance capacity with $3,57 \mathrm{ml} / \mathrm{gr}$, followed by Sonneratia casiolaris with 1,46 ml/gr and Avicennia marina with 2,33 ml/gr. Starch obtained from Bruguiera gymnorrhiza, Sonneratia casiolaris and Avicennia marina by immersing it using $0 \%$ natrium metabisulfite has the smallest water absorbance capacity with $3,02 \mathrm{ml} / \mathrm{gr}$, $1.17 \mathrm{ml} / \mathrm{gr}$ and $1,92 \mathrm{ml} / \mathrm{gr}$, respectively. Different concentration of natrium metabisulfite has significant effect toward water absorbance capacity. Higher water absorbance capacity means higher starch quality, since its rising capacity would be larger. Immersion process using natrium metabisulfite in long duration would produce high water absorbance capacity. This process occurs since natrium metabisulfite was capable in penetrating tissue cell walls thus resulting higher water absorption capacity (Rahman and Perera, 1999). Water absorbance capacity analysis results for starch can be seen in Figure 6 and Figure 7. 


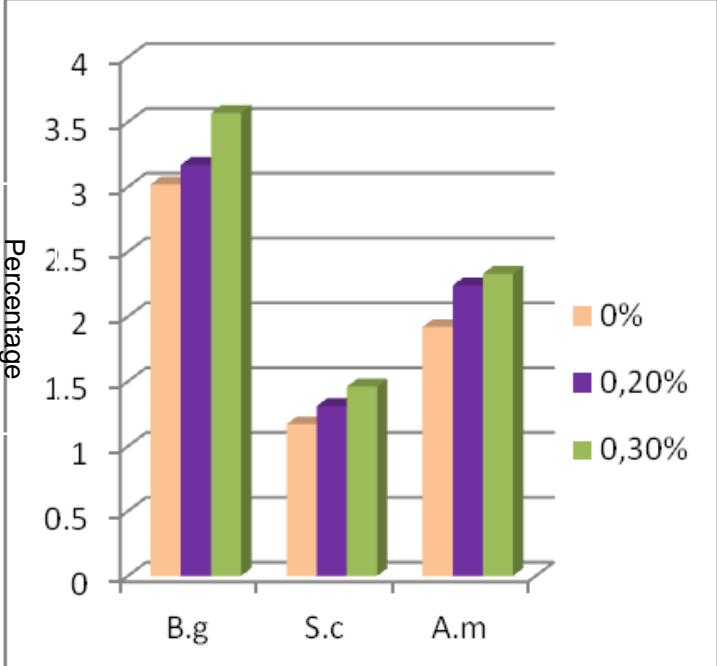

B.g =Bruguiera gymnorrhiza

S.c = Sonneratia casiolaris

A.m = Avicennia marina

Figure 6. Water absorbance capacity for starch (concentration)

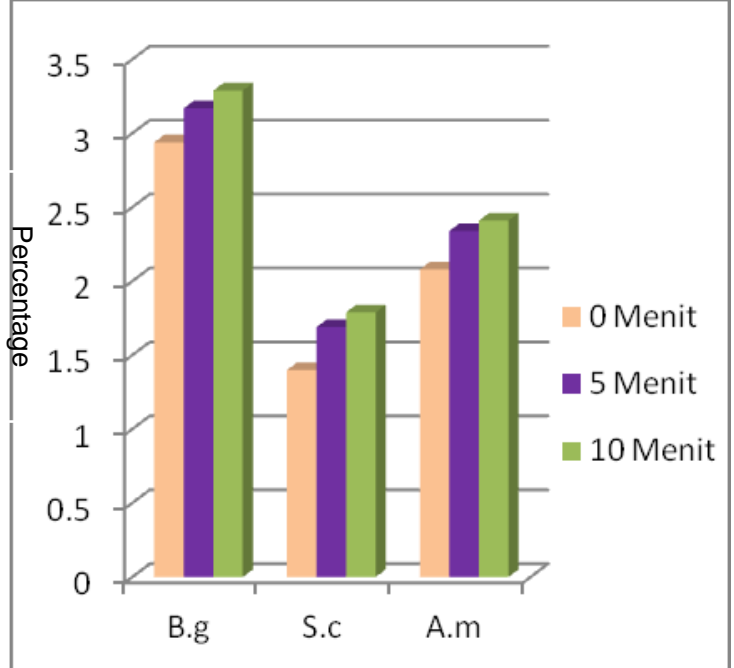

B.g = Bruguiera gymnorrhiza

S.c = Sonneratia casiolaris

A.m = Avicennia marina

Figure 7. Water absorbance capacity for starch (time)

\subsection{Characterization for Chemical Traits}

\section{Water content}

This study results indicate that water content for starch of Bruguiera gymnorrhiza was range between 9,02\%-10,77\%. Water content in material would affect its shelf life, higher water content means material will be easily damaged in short period of time. This occurs due to microbes will grow faster in material with high water content, whereas microbes activity benchmark would range between 14\%-15\% water content in a material (Fardiaz, 1989). Result of this study also found out that natrium metabisulfite concentration has significant effect toward starch's water content of Bruguiera gymnorrhiza.

Water content for starch of Sonneratia casiolaris range between 10,72\%-11,90\%, a bit higher than water content for starch of Bruguiera gymnorrhiza, which was due to physical shape of Bruguiera gymnorrhiza. Its physical form was propagule which was buds germinated in tree, while starch source of Sonneratia casiolaris was its fruit that contain more water. Result of this study also showed that natrium metabisulfite concentration has significant effect toward starch's water content of Sonneratia casiolaris.

Water content for starch of Avicenia marina was ranged between 7,69\%-9,61\%, this result showed differences compared to starch from Bruguiera gymnorrhiza and Sonneratia casiolaris, it might be due to source used in this study was in grain form of Avicennia marina, with less water content and proven by significant effect of natrium metabisulfite concentration toward starch's water content of Avicennia marina.

In Table 3.1, it showed that longer duration of submerging using natrium metabisulfite resulting in higher starch's water content for Bruguiera gymnorrhiza, Sonneratia casiolaris 
and Avicennia marina. This condition showed that longer immersion treatment resulting more water transport into material thus it has more water content. Immersing material in natrium metabisulfite within 0 minutes show the lowest water content. It means that starches of Bruguiera gymnorrhiza, Sonneratia casiolaris and Avicennia marina with lower water content would be more resistant toward microbe's growth.

Table 3.2 showed that higher natrium metabisulfite concentration resulting higher water content in starch of Bruguiera gymnorrhiza, Sonneratia casiolaris and Avicennia marina. According to Rahman and Perera (1998), this water content increase would related with sulfatation process that could cause material's tissue cells or its starch granule become more porous thus accelerate drying process and with faster drying process faster evaporation would occurs.

\section{Ash content}

Study showed that starch's ash content of Bruguiera gymnorrhiza ranged between $4,65 \%$ $5,65 \%$. Quantitatively, ash content value in starch would come from its mineral within hypocotyl and fresh fruits, but it might also came from soil and air contamination during processing (Soebito, 1988). Result in this study indicated that immersion duration in natrium metabisulfite has significant effect toward starch's ash content of Bruguiera gymnorrhiza. From this result, it was known that longer duration in immersion using natrium metabisulfite means lower ash content in its starch. This condition is in accordance with Isnaharani (2009), who suggest that immersing or soaking material in natrium metabisulfite would cause several mineral being diluted into water thus the longer it occurs, more mineral would be diluted into water and causing lower ash content. For starch of Bruguiera gymnorrhiza, in immersion using natrium metabisulfite for 10 minutes $(4,65 \%)$ would resulting lower ash content compared to starch of Bruguiera gymnorrhiza that was immersed in 0 and 5 minutes $(5,95 \%)$ and (5,84\%). Meanwhile, effect of immersion's duration toward ash content in starch of Sonneratia casiolaris was ranged (4,10\% - 4,17\%) and Avicennia marina was ranged $(3,87 \%$ $4,16 \%$ ) as can be seen in Table 1, Table 2 and Table 3.

Regarding natrium metabisulfite concentration, result of this study showed that ash content of starch from Bruguiera gymnorrhiza ranged between 5,65\% - 5,68\%. Quantitatively, ash content value in starch would come from its mineral within hypocotyl and fresh fruits, but it might also came from soil and air contamination during processing (Soebito, 1988). Result of this paper showed that natrium metabisulfite concentration has affecting ash content of starch from Bruguiera gymnorrhiza. This might be due to $\mathrm{Na}$ and $\mathrm{S}$ mineral content within natrium metabisulfite. Ash content of a material might be associated with minerals contained in it (Rahman, 2007). This condition also hold for starch from Sonneratia casiolaris with ash content for solution concentration ranged (4,60\% - 4,65\%), while Avicennia marina has ash content for solution concentration ranged $(4,79 \%-5,18 \%)$, as can be seen in Table 4 Table 5 and Table 6.

\section{Protein}

Result of this study showed that protein content in starch of Bruguiera gymnorrhiza with 
various immersion duration ranged between $2,57 \%-2,68 \%$, while with various natrium metabisulfite concentration ranged between 3,21\% - 3,31\%. For starch of Sonneratia casiolaris with various immersion duration ranged between 1,22\% - 1,23\%, while with various natrium metabisulfite concentration ranged between 1,67\% - 1,69\%. Starch from Avicennia marina with various immersion duration ranged between $1,77 \%-1,89 \%$ while with various natrium metabisulfite concentration ranged between 2,08\% - 2,20\%. It means that both treatment, immersion duration and natrium metabisulfite concentration has significant effect toward protein content in starch of Bruguiera gymnorrhiza, Sonneratia casiolaris and Avicennia marina.

\section{Fat}

Result of this study showed that fat content in starch of Bruguiera gymnorrhiza with various immersion duration ranged between $0,66 \%-0,89 \%$, while with various natrium metabisulfite concentration ranged between $0,22 \%$ - 0,24\%. For starch of Sonneratia casiolaris with various immersion duration ranged between $0,54 \%-0,55 \%$, while with various natrium metabisulfite concentration ranged between $0,11 \%-0,14 \%$. Starch from Avicennia marina with various immersion duration ranged between $0,57 \%-0,58 \%$ while with various natrium metabisulfite concentration ranged between $0,92 \%-0,94 \%$. It means that immersion duration and natrium metabisulfite concentration has significant effect toward fat content in starch of Bruguiera gymnorrhiza, Sonneratia casiolaris and Avicennia marina. Increasing fat content either in immersion duration treatment or natrium metabisulfite concentration treatment means that immersion duration and natrium metabisulfite concentration has significant effect toward fat content, this is in accordance with Rahman and Perera (1998) who suggest that natrium metabisulfite concentration and immersion duration would cause tissue's cells in material became porous and fat were split into fatty acid. Thus longer immersion in natrium metabisulfite would increase fat content of material. This occurs for three starches, as can be seen in Table 6.

\section{Crude fiber}

Result showed that crude fiber for starch of Bruguiera gymnorrhiza, Sonneratia casiolaris, and Avicennia marina with varying immersion duration and natrium metabisulfite concentration also has significant effect toward crude fiber content. Longer duration in immersion means lower crude fiber content. This is in accordance with Wahid et al. (1992) who suggest that if starch content in material reach optimum, starch would decreasing gradually and starch would start becoming fiber, analysis result was given in Table 1 until Table 6.

\section{Starch}

Result of this study showed that starch content in Bruguiera gymnorrhiza, Sonneratia casiolaris and Avicennia marina has increase along with longer duration of immersion and higher natrium metabisulfite concentration which means it has significant effect. Result for starch content of Bruguiera gymnorrhiza, Sonneratia casiolaris and Avicennia marina ranged between $57,21 \%-73,19 \%, 57,19 \%-61,95 \%$ and $69,78 \%-70,71 \%$ respectively. We found 
out that variable's effect would change for starch processing from hypocotyl of Bruguiera gymnorrhiza, fruit of Sonneratia casiolaris and fruit of Avicennia marina. The higher natrium metabisulfite concentration, reduction sugar content would be lower. This was due to natrium metabisulfite trait that acts as an oxydator and as bleaching agent or oxidative bleaching (pulp bleaching).

\section{Amylose content}

Result of this study showed that amylose content of Bruguiera gymnorrhize with varying immersion duration ranged between $19,34 \%$ - 23,10\%, while with varying natrium metabisulfite concentration ranged between $31,38 \%$ - 31,45\%. For starch of Sonneratia casiolaris with varying immersion duration ranged between $19,56 \%-20,22 \%$, while with varying natrium metabisulfite concentration ranged between $20,25 \%-20,28 \%$. Starch from Avicennia marina with varying immersion duration ranged between 27,15\% - 27,39\% while with varying natrium metabisulfite concentration ranged between $27,45 \%-27,69 \%$. It showed that immersion duration and natrium metabisulfite concentration has significant effect toward increasing amylose content. Amylose and amylopectin was highly important due gelatinization process, retrogradation and also determining starch's paste characteristic (Jane et al., 1999). Also Smith (1982) showed that starch with high amylose content would have larger hydrogen bond due to more straight chains in its granules, thus it would consume more energy for gelatinization.

Table 1. Chemical Trait of Starch Bruguiera gymnorrhiza with varying immersion duration

\begin{tabular}{cccccccc}
\hline $\begin{array}{c}\text { Duration of } \\
\text { immersion }\end{array}$ & $\begin{array}{c}\text { Water } \\
\text { content }\end{array}$ & $\begin{array}{c}\text { Ash } \\
\text { content }\end{array}$ & Protein & Fat & Coarse fiber & Starch & Amylose \\
0 Minutes & $9,32^{\mathrm{a}}$ & $5,95^{\mathrm{b}}$ & $2,57^{\mathrm{a}}$ & $0,89^{\mathrm{a}}$ & $1,34^{\mathrm{c}}$ & $65,23^{\mathrm{a}}$ & $23,10^{\mathrm{a}}$ \\
5 Minutes & $9,78^{\mathrm{a}}$ & $5,84^{\mathrm{b}}$ & $2,67^{\mathrm{a}}$ & $0,78^{\mathrm{a}}$ & $1,40^{\mathrm{a}}$ & $67,11^{\mathrm{a}}$ & $19,34^{\mathrm{a}}$ \\
10 Minutes & $10,77^{\mathrm{b}}$ & $4,65^{\mathrm{b}}$ & $2,68^{\mathrm{b}}$ & $0,66^{\mathrm{a}}$ & $1,31^{\mathrm{b}}$ & $67,21^{\mathrm{b}}$ & $21,34^{\mathrm{c}}$ \\
\hline
\end{tabular}

Table 2. Chemical Trait of Starch Bruguiera gymnorrhiza with varying solution concentration

\begin{tabular}{cccccccc}
\hline Concentration $\%$ & $\begin{array}{c}\text { Water } \\
\text { content }\end{array}$ & $\begin{array}{c}\text { Ash } \\
\text { content }\end{array}$ & Protein & Fat & Coarse fiber & Starch & Amylose \\
$0 \%$ & $9,28^{\mathrm{b}}$ & $5,65^{\mathrm{a}}$ & $3,21^{\mathrm{a}}$ & $0,22^{\mathrm{c}}$ & $0,62^{\mathrm{a}}$ & $71,63^{\mathrm{a}}$ & $31,38^{\mathrm{a}}$ \\
$5 \%$ & $9,11^{\mathrm{a}}$ & $5,67^{\mathrm{b}}$ & $3,26^{\mathrm{a}}$ & $0,24^{\mathrm{a}}$ & $0,58^{\mathrm{b}}$ & $69,21^{\mathrm{a}}$ & $31,41^{\mathrm{a}}$ \\
$10 \%$ & $9,02^{\mathrm{a}}$ & $5,68^{\mathrm{b}}$ & $3,31^{\mathrm{c}}$ & $0,23^{\mathrm{a}}$ & $0,32^{\mathrm{c}}$ & $73,19^{\mathrm{a}}$ & $31,45^{\mathrm{a}}$ \\
\hline
\end{tabular}

Table 3. Chemical Trait of Starch Sonneratia casiolaris with varying immersion duration

\begin{tabular}{cccccccc}
\hline $\begin{array}{c}\text { Duration of } \\
\text { immersion }\end{array}$ & $\begin{array}{c}\text { Water } \\
\text { content }\end{array}$ & $\begin{array}{c}\text { Ash } \\
\text { content }\end{array}$ & Protein & Fat & $\begin{array}{c}\text { Coarse } \\
\text { fiber }\end{array}$ & Starch & Amylose \\
0 Minutes & $11,78^{\mathrm{a}}$ & $4,17^{\mathrm{a}}$ & $1,22^{\mathrm{b}}$ & $0,54^{\mathrm{a}}$ & $0,39^{\mathrm{b}}$ & $57,19^{\mathrm{a}}$ & $19,56^{\mathrm{b}}$ \\
5 Minutes & $11,81^{\mathrm{a}}$ & $4,13^{\mathrm{a}}$ & $1,23^{\mathrm{a}}$ & $0,55^{\mathrm{b}}$ & $0,38^{\mathrm{b}}$ & $57,21^{\mathrm{a}}$ & $19,56^{\mathrm{a}}$ \\
10 Minutes & $11,90^{\mathrm{b}}$ & $4,10^{\mathrm{c}}$ & $1,23^{\mathrm{a}}$ & $0,55^{\mathrm{b}}$ & $0,39^{\mathrm{a}}$ & $59,32^{\mathrm{a}}$ & $20,22^{\mathrm{a}}$ \\
\hline
\end{tabular}


Table 4. Chemical Trait of Starch Sonneratia casiolaris with varying solution concentration

\begin{tabular}{cccccccc}
\hline Concentration $\%$ & $\begin{array}{c}\text { Water } \\
\text { content }\end{array}$ & $\begin{array}{c}\text { Ash } \\
\text { content }\end{array}$ & Protein & Fat & $\begin{array}{c}\text { Coarse } \\
\text { fiber }\end{array}$ & Starch & Amylose \\
$0 \%$ & $10,89^{\mathrm{a}}$ & $4,60^{\mathrm{a}}$ & $1,67^{\mathrm{c}}$ & $0,11^{\mathrm{a}}$ & $0,42^{\mathrm{b}}$ & $58,26^{\mathrm{a}}$ & $20,25^{\mathrm{b}}$ \\
$5 \%$ & $10,74^{\mathrm{a}}$ & $4,62^{\mathrm{a}}$ & $1,69^{\mathrm{a}}$ & $0,13^{\mathrm{a}}$ & $0,43^{\mathrm{a}}$ & $61,94^{\mathrm{b}}$ & $20,27^{\mathrm{a}}$ \\
$10 \%$ & $10,72^{\mathrm{a}}$ & $4,65^{\mathrm{a}}$ & $1,69^{\mathrm{a}}$ & $0,14^{\mathrm{a}}$ & $0,51^{\mathrm{a}}$ & $61,95^{\mathrm{b}}$ & $20,28^{\mathrm{c}}$ \\
\hline
\end{tabular}

Table 5. Chemical Trait of Starch Avicennia marina with varying immersion duration

\begin{tabular}{cccccccc}
\hline $\begin{array}{c}\text { Duration of } \\
\text { immersion }\end{array}$ & $\begin{array}{c}\text { Water } \\
\text { content }\end{array}$ & $\begin{array}{c}\text { Ash } \\
\text { content }\end{array}$ & Protein & Fat & $\begin{array}{c}\text { Coarse } \\
\text { fiber }\end{array}$ & Starch & Amylose \\
0 Minutes & $8,32^{\mathrm{a}}$ & $4,16^{\mathrm{a}}$ & $1,77^{\mathrm{a}}$ & $0,57^{\mathrm{a}}$ & $0,89^{\mathrm{a}}$ & $70,03^{\mathrm{b}}$ & $27,39^{\mathrm{a}}$ \\
5 Minutes & $8,68^{\mathrm{a}}$ & $4,01^{\mathrm{b}}$ & $1,81^{\mathrm{a}}$ & $0,58^{\mathrm{a}}$ & $0,90^{\mathrm{b}}$ & $69,78^{\mathrm{a}}$ & $27,27^{\mathrm{a}}$ \\
10 Minutes & $9,61^{\mathrm{a}}$ & $3,87^{\mathrm{b}}$ & $1,89^{\mathrm{a}}$ & $0,58^{\mathrm{a}}$ & $0,90^{\mathrm{b}}$ & $70,31^{\mathrm{c}}$ & $27,15^{\mathrm{a}}$ \\
\hline
\end{tabular}

Table 6. Chemical Trait of Starch Avicennia marina with varying solution concentration

\begin{tabular}{cccccccc}
\hline Concentration $\%$ & $\begin{array}{c}\text { Water } \\
\text { content }\end{array}$ & $\begin{array}{c}\text { Ash } \\
\text { content }\end{array}$ & Protein & Fat & $\begin{array}{c}\text { Coarse } \\
\text { fiber }\end{array}$ & Starch & Amylose \\
$0 \%$ & $8,34^{\mathrm{b}}$ & $4,79^{\mathrm{a}}$ & $2,08^{\mathrm{b}}$ & $0,92^{\mathrm{b}}$ & $0,92^{\mathrm{c}}$ & $70,29^{\mathrm{a}}$ & $27,45^{\mathrm{a}}$ \\
$5 \%$ & $7,79^{\mathrm{b}}$ & $4,84^{\mathrm{a}}$ & $2,12^{\mathrm{a}}$ & $0,94^{\mathrm{a}}$ & $0,94^{\mathrm{b}}$ & $70,67^{\mathrm{b}}$ & $27,67^{\mathrm{c}}$ \\
$10 \%$ & $7,69^{\mathrm{a}}$ & $5,18^{\mathrm{a}}$ & $2,20^{\mathrm{a}}$ & $0,94^{\mathrm{a}}$ & $0,99^{\mathrm{b}}$ & $70,71^{\mathrm{c}}$ & $27,69^{\mathrm{a}}$ \\
\hline
\end{tabular}

\section{Conclusion}

From result of this study, it can be concluded that longer duration in immersion and higher concentration of natrium metabisulfite would give significant effect toward starch of Bruguiera gymnorrhiza, Sonneratia casiolaris and Avicennia marina. Water content of starch from Bruguiera gymnorrhiza ranged between 9,02\%-10,77\% while water content of Sonneratia casiolaris ranged between $10,72 \%$ - 11,90\%. Meanwhile water content of Avicennia marina ranged between 7,69\% - 9,61\%. Ash content of Bruguiera gymnorrhiza ranged between $4,65 \%-5,65 \%$, while for Sonneratia casiolaris was ranged between 4,10\% 4,17\% and Avicennia marina has ash content ranged between 3,87\% - 4,16\%. Highest protein content for each type was Bruguiera gymnorrhiza 3,31\%, Sonneratia casiolaris 1,69\% and Avicennia marina 2,20\%. Fat content for these three mangroves were $0,89 \%, 0,58 \%$ and $0,94 \%$. Coarse fiber content were $1,40 \%, 0,51 \%$ and $0,99 \%$. High starch content ranged between 57,21\% - 73,19\%; 57,19\% - 61,95\% and 69,78\% - 70,71\%, respectively. Amylose content would ranged between $19,34 \%-23,10 \% ; 31,38 \%-31,45 \%$ for both treatment in Bruguiera gymnorrhiza and 19,56\% - 20,22\%; 20,25\% - 20,28\% for Sonneratia casiolaris also between 27,15\% - 27,39\%; 27,45\% - 27,69\% for Avicennia marina. Thus, these three mangroves have the potential to become starch sources and functioned as food sources.

\section{References}

AOAC. (1990). Official Methods of Analysis of the Association of Official Analytical Chemists, Volume one, 15 ht Edition Washington. 
AOAC. (1998). Official Methods of Analysis of the Association of Analytical Chemistry Inc., Washington D.C.

Ardiansyah. (2005). Functional Food Safety of Food-Based Traditional. [Online] Available: http // www.beritaiptek.com / zberita / Tuesday 20 June 2006. Articles Science - Biology Division, Food and Health.

Association of Official Analytical Chemists, (1984)14 ht ed AOAC, Ins Arington Virginia.

Bello-Pe'rez, L. A., Religion-Acevedo, E., Sa'nchez-Herna'ndez, L., \& Paredes-Lo'pez, O. (1999). Isolation and Partial characterization of Banana starches. Journal of Agricultural and Food Chemistry, 47, 854-857.

Cadden, A. M. (1987). Comparative effect of particle size reduction on the physical structure and water binding properties of Several plant fibers. Journal of food sainche, 52, 1595-1599.

Fardiaz, S. (1989). Food Microbiology. Department of Food Technology and Nutrition. Fateta IPB. Bogor.

French, D. (1984). Organization of starch granules. In R.L. Whistler, J.N. Bemmiler and E.F. Paschall (eds) Starch: Chemistry and Technology. Academic Press Inc. New York.

Isnaharani, Yulan. (2009). Utilization of Wheat Straw Jackfruit (Artocarpus heterophyllus) Lmk. In Making High Fiber Cookies. Bogor: Faculty of Human Ecology, IPB.

Jane, J., Y. Y. Chen, L.F. Lee, A. E. McPherson, K. S., Wong, M., adosavljevics, \& T. Kasemsuwan. (1999). Effect of brain amylopectin and amylose content of chain length on the gelatinization and pasting properties of starch. Cereal Chem, 76(5), 629-637.

Juliano, B. 0. (1971). A simplified assay for milled-rice amylose. CerealbSci. Today, 16, 334.

Leach, H.W. (1965). Gelatinization of starch. In Whisler, R. L., \& E.F. Paschall (Eds.), Starch Chemistry and Technology, Vol 1. Academic Press, New York.

Pentury, M. H. (2009), Assessment of Mangrove Forest Potential In Effort Traditional Food Supply. Bulletin Dynamics Kopertis Region XII, 2, 39-47.

Reira, RC, et al., (2008). Relationship between structural and biochemical characteristics and texture of corn grains. Genetics and molecular research, 7, 498-508.

Santoso, M., Holil, M., \& Alfarisi, S. (2009). Making 4-Formal-2-methoxyphenyl isobutyrate from Clove Leaf. The National Science Seminar II, Bogor, 13-14 November.

Smith, P. S. (1982). Starch Derivatives and Their Uses in Foods. In the G.M.A. Van Beynum \& J. A. Rolls (Eds.), Food Carbohydrate. 1982. AVI. Publ. Co. Inc., Westport, Connecticut.

Soebito, S. (1988). Analysis of Pharmaceuticals. Gadjah Mada University Press. Yogyakarta.

Syarief, R., \& Irawati, A. (1988). Knowledge for Food Ingredients Industry. Mediyatama Sarana Perkasa, Jakarta.

Wahid, U. S., Richana, N., \& Jamaladin, C. (1992). Influence of harvesting and fertilization 
on yield and quality of cassava varieties of ivory and Adira-4. Titian Agronomy. Bulet in Agronomy Research, 1(1).

Widiyowati, Iis Intan. (2007). Effect of Long Immersion and levels of Sodium metabisulphite in Solution Soaking in Pieces Yellow Sweet Potato (Ipomoea Batatas (L.) Lamb) on the Quality of Flour Generated. Chemical Education FKIP-Unmul, Jl. Muara Pahu Campus Unmul Mount Kelua Samarinda.

\section{Copyright Disclaimer}

Copyright for this article is retained by the author(s), with first publication rights granted to the journal.

This is an open-access article distributed under the terms and conditions of the Creative Commons Attribution license (http://creativecommons.org/licenses/by/3.0/). 